AÜiFD 47 (2006), sayı 2, s. 143-164

\title{
C. H. Becker (1876-1933) Örneğinde Uygulamalı Oryantalizm (Angewandte Orientalistik) Anlayışı-Oryantalizm Çalışmalarının Siyasallaşma Süreci
}

\author{
ÖZCAN TASSCI \\ DR., ÇANAKKALE ONSEKIZ MART Ü. İLAHIYAT FAKÜLTESI \\ e-mail: ozzcan12@hotmail.com
}

\begin{abstract}
The applied Orientalism and C. H. Becker in its System- The politicalprocess of the Oriental Studies. In this article, we tried to explain the politicalprocess of the oriental Studies in its History and development. This period of the studies of the applied Orientalism appeared generally in IXth century, which related with the western colonialism. Then it was the important subject for his appearence in the History. The important principle of this applied Orientalism is, that the oriental Studies are made for the political goals and C. H. Becker was the important orientalist of this applied Orientalism.
\end{abstract}

key words: Applied Orientalism, C. H. Becker, the Politicalprocess of the Oriental Studies, Colonialism.

\section{A. Giriş}

Oryantalizm çalışmalarını temelde üç safhaya ayırmak mümkündür: ${ }^{1}$ Çalışmaların dinsel polemik amacıyla ve Müslümanlara karşı mutlak bir önyargıyla yapıldığı birinci safha, İslam'ın doğuşundan kısa bir süre sonra başlayıp Rönesans ve Aydınlanma dönemine kadar geçen süreyi içermektedir. ${ }^{2}$ İkinci safha ise Rönesans ve Aydınlanma dönemiyle (16. yüzyılın sonu ve 19. yüzyılın ilk çeyreği) birlikte başlamaktadır. ${ }^{3}$ Oryantalizm çalışmaları-

1 Krş., Watt, W. Montgomery- Welch, Alford T.: Der İslam, Bd. I, Stuttgart u.a. 1980 (Die Religionen der Menschheit. 25, 1), s. 17-38.

2 a.g.e., s. $17-23$

3 Bkz., a.g.e., s. 23-28. 
nın modern anlamda başlaması ve daha da geliştirilmesi, bu dönemin en önemli özelliği olarak gösterilmektedir. ${ }^{4}$ Özellikle 17 . yüzyılın sonlarına doğru filoloji çalışmalarına önem verilmesiyle, ${ }^{5}$ Arapça öğretimi ve Kur'an'ı Arapça aslından tercüme edilmesi konularında ilerlemeler kaydedilmiştir. ${ }^{6}$ Bazı Batılı kaynaklar bu dönemdeki oryantalizm çalışmalarının, ilk dönemden farklı olarak, bilimsel bir kimliğe kavuştuğu savını ileri sürmektedirler. ${ }^{7}$ Oysa bu iddia gerçeği tam olarak yansıtmamaktadır, zira her ne kadar aralarında, bilimlerin birbirinden ayrılması (oryantalizm de bu gelişmeye paralel olarak dini-teolojik ilimlerden ayrılarak yavaş yavaş bağımsız bir ilim dalı olmaya başlamıştır ${ }^{8}$ ) ve buna bağlı olarak da her bilimin kendine ait bir yönteminin oluşmasının etkisiyle ${ }^{9}$, bilgi edinmek gayesiyle, bilimsel metotlarla yapılanlar ${ }^{10}$ bulunsa da, bu çalışmaların büyük çoğunluğu ilk dönemde yaygın olan ön yargı ve dini polemik geleneğinin doğal bir sonucu olan "çarpık bir İslam anlayışının gölgesinde" (unter dem Einfluss des verzerrten İslambildes) yürütülmüşlerdir. ${ }^{11}$ Bununla birlikte, bu dönemdeki çalışmaların ilk döneme nazaran, daha modern ve bilimsel bir görünüm kazandığı gerçeği inkâr edilemez.

Oryantalizm çalışmalarının üçüncü dönemi ise genel anlamda 19. yüzyılın ikinci çeyreğiyle (1830'dan sonra), yani Batının Müslüman ülkelerdeki yayılmacl/sömürge edinme faaliyetlerinin yoğunlaştı̆̆ bir dönemle başlayıp, takriben II. Dünya savaşına kadar devam eder. ${ }^{12}$ Bu dönem süresince yapılan oryantalizm çalışmalarını öncekilerden ayıran en önemli unsur, onların, Müslüman sömürgelerde takip edilecek günlük siyasette yani, pratik-gerçek hayatta doğrudan uygulanmak gaye ve hedefiyle yapılmış olmasıdır. Bundan başka, oryantalistlerin, Müslüman sömürgelerde, önce devlet memuru, daha

4 Bkz. Deutsche Orientalistik (hrsg. Orientalisches Seminar der Üniversität Tübingen), Tübingen 1974, s. 7.

5 Felix Klein- Franke, Die Klassische Antike in der Tradition des İslam, Darmstadt 1980, s. 53.

6 Watt-Welch, a.g.e., s. 26.

7 "Batı'da, İslam üzerine çalışmalar, en önce bu dinin mensuplarını tanımak, daha sonra ise onları dinlerinden döndürmek için yapılmıştır. Ancak, bu ilk dönemde polemikle eşdeğer olan Doğu araştırmaları, özellikle "aydınlanma döneminde", tam anlamıyla bilimsel bir karaktere bürünmüştür."Gesammelte Schriften von Ignaz Goldzieher (hrsg. Joseph Desomogy1), I., s. VII.

8 Rudi Paret, Arabistik und İslamkunde an deutschen Universitäten, Wiesbaden 1966, s. 5; Johan Fück, Die arabischen Studien İn Europa vom 12. bis in den Anfang des 19. Jahrhunderts, s. 11.

9 H. H. Schaeder, "Asien und Ostgrenze der europäischen Kultur", in: Der Orient in deutscher Forschung, Vorträge der Berliner Orientalistentagung 1942, Leipzig 1944, s. 7-8.

10 Bu konuda Johann Wolgang Goethe (1749-1832) 'yi örnek olarak verebiliriz: "Yunan vezninin Alman şiirinde taklit edilmesi o kadar bıkkınlık verdi ki, 65 yaşındaki Göethe, Doğu şiirinin çekiciliğine kendisini kaptırdı ve Hafız’ın yazdığı şiirler gibi yazmaya çalıştı.” Franke, a.g.e., s. 109.

11 Watt-Welch, a.g.e., s. 27. (Bu dönemin önemli düşünür ve oryantalistlerinin İslam'a ve Müslümanlara bakış açıları için bkz., Franke, a.g.e., s. 53-109).

12 Franke, a.g.e., s. 28-36. 
sonra ise bizzat siyasetçi ve devlet adamı olarak, genelde devlet ve hükümet siyasetinde, özelde ise sömürge faaliyetlerinde aktif rol üstlenmiş olmaları; yaptıkları araştırma ve çalışmalardan elde ettikleri verileri de takip ettikleri politika ve siyasetin yararına doğrudan pratik hayatta uygulamış olmaları, ${ }^{13}$ bu dönemin öne çıkan diğer bir özelliğidir. Başka bir ifadeyle, onlar bilimsel faaliyetlerini teorik-soyut alandan, pratik-somut alana kaydırmış olmaktadırlar. Bu durum, görebildiğimiz kadarıyla, oryantalizm tarihinde oldukça yeni bir gelişme olarak karşımıza çıkmaktadır. Şu halde, temelde Batı'nın yayılmacı siyaset anlayışının bir eseri olarak ortaya çıkan ${ }^{14}$ ve büyük oranda politiksiyasal gaye ve hedeflerle yapılan ${ }^{15}$, bu anlamda da bir bakıma "siyasal oryantalizm" olarak da isimlendirilebilecek ${ }^{16}$ bu oryantalist yaklaşım ve ekol, "uygulamalı oryantalizm" (Alm. angewandte, gegenwartsbezogene Orientalistik; İng. applied orientalism) olarak adlandırılmaktadır. ${ }^{17}$ Bu akım en sonunda, II. Dünya Savaşı'ndan itibaren "global sosyoloji" ye dönüşmüştür. ${ }^{18}$ İşte bu makalede, 'uygulamalı' oryantalizm akımının Avrupa ve özellikle de Almanya'daki gelişim sürecini ve bunun oryantalist çalışmalara olan etkisini C.H. Becker (ö. 1933) örneğinde inceleyeceğiz.

\section{B. Uygulamalı Oryantalizm (angewandte/gegenwartbezogene Orientalistik)}

1. Uygulamalı Oryantalizm'in Başlangıcı: Batı́nın Sömürge Faaliyetlerinin Uygulamalı Oryantalizm'in Ortaya Çıkmasındaki Etkileri

Müslüman ülkelerde Batılı devletlerin hızla artan kolonileşme-yayılmacı politikaları, oryantalizm çalışmalarının muhtevasını da bu politikaya para-

13 Bkz., Watt-Welch, a.g.e., s. 33-34.; Ludmila Hanisch, "Gelehrten Selbstverständnis, wissenschaftliche Rationalität und politische Emotionen”, Die Welt des Íslams, Bd. 32, Nr. 1. (1992), s. 107-108.

14 Peter Heine, Ethnologie des Nahen und Mittleren Ostens, Berlin 1989, s. 28.

15 S. Turner Bryan, Oryantalizm, Postmodernizm ve Globalizm, çev. İbrahim Kapaklıkaya, İstanbul 2002, s. 148. ; Heine, a.g.e., s. 30.

16 Bkz., C. H. Becker, İslam'ın dini değil, politik bir sorun olduğunu açıkça dile getirmektedir: "İslam meselesi her şeyden önemli politik bir koloni/sömürge meselesidir...", "Staat und Mission in der İslamfrage" İslamstudien, Bd. II, Leipzig 1932, s. 211; "İslam problemi, çoğunlukla dini bir mesele olarak değerlendirilmektedir, oysa İslam sadece bir din değil, aynı zamanda bir medeniyet ve siyasal bir düşüncedir (Staatsgedanke)...Bundan dolayı da İslam meselesini dâhili ve harici politik bir mesele olarak görmek daha anlamlı ve isabetli olacaktır." "İslampolitik", İslamstudien, Bd. II, Leipzig 1932, s. 310.

17 Peter Heine, "C.Snouck-Hurgronje Versus C.H.Becker. Ein Beitrag zur Geschichte der angewandten Orientalistik", in: Die Welt des İslams 23/4 (1984), s. 387; Hanisch, a.g.m., s. 107.

18 Bryan, a.g.e., s. 147. 
lel olarak büyük bir değişikliğe uğratmıştır. Napolyon'un 1798'de Mısır'a yaptığı sefer, bu durumu en açık şekilde gözler önüne sermektedir. "Sözü edilen bu seferde, sadece askerler değil, aynı zamanda 'Mission de 1'Egypte' olarak isimlendirilen ve Doğa bilimcileri, Arkeolog, dil bilimcileri ve o dönem için, teorik olarak henüz daha sistemleşmemiş olan sosyal bilimler alanında çalışmalar yapan bilim adamlarından oluşan bir grup da katılmıştı. ${ }^{19}$ Onların görevi, "Mısırlı fellahların, yaşam biçimlerini, hukuk sistemlerini, akrabalık ilişkilerini ya da çalışma tekniklerini incelemek ve analiz etmekti..." ${ }^{20}$ Misir'da uygulanan bu yöntemin daha sonra Cezayir'de de uygulandığı ve oldukça önemli sonuçlar verdiği görülmüştür. Örneğin, işgalin ardından, direniş gösteren bölgelerde, direnişteki en önemli faktörün "Cezayir kabilelerinin Fransız işgaline sonuna kadar karşı oldukları", Fransız oryantalistlerin sözü edilen bölgelerde yapmış oldukları etnolojik çalışmalar sayesinde tespit edilmiştir. ${ }^{21}$ Bu örnekte de görüleceği üzere, "ele geçirilen her bölgede, işgale karşı direnen tüm kabileler, direnişin arkasında yatan etken sebeplerin tespiti amacıyla, muhakkak etnolojik açıdan bir tahlile tabi tutuluyorlardı."22 Zira, Mısır ve Cezayir örneğinde olduğu gibi, ele geçirilen bölgelerde azami sürede kalmak ve buralardan azami derecede faydalanmak, sözü edilen bölgeleri ve bölge insanını en iyi şekilde incelemek ve analiz etmeye bağlıydı. Bu da ancak oryantalizm çalışmalarıyla mümkün olabilirdi. Çünkü "...artık teorik bilgi stratejik bir önem kazanmıştı..."23 Bunun için, oryantalizm çalışmalarının sistematik ve modern-bilimsel metot ve yöntemlerle öğretilebilmesi, buna bağlı olarak da, başta İslam ülkeleri ve Müslümanlar olmak üzere Doğu'nun dilini, kültürünü ve inanç sistemini yüksek seviyede bilen oryantalistlerin yetiştirilmesi amacıyla, birçok okul ve Enstitü kuruldu. Avrupa'da, bilimsel metotlarla Arapça'nın da öğretildiği akademilerin ilk örneğini, 1795'te Silvestre de Sacy (ö. 1838) tarafından Paris'te kurulan "Oryantal dilleri Okulu" teşkil etmektedir. ${ }^{24}$ Bu okulu Avrupa'nın diğer şehirlerinde kurulanları takip etti. Bu enstitülerde yetişen oryantalistler, gerektiğinde askeri seferlere katılıyorlar ve sömürgeci güçlere bilimsel açıdan da bir tür lojistik destek sağlıyorlardı. ${ }^{25}$ Böylece, Fransa'nın yayılmacı girişimlerini, ortaya koyduğu verilerle destekleyen ve hızlandıran

19 Heine, a.g.e., s. 28; krş., M. Çetin Nihad, "Arap Dili”, T.D.V. İslam Ansiklopedisi, İstanbul 1991, c. 3, s. 285.

20 Heine, a.g.e., 28.

21 a.g.e., s. 28.

22 a.g.e., s. 28.

23 Hanisch, a.g.m., s. 109, dip not 13.

24 Deutsche Orientalistik, s. 10.

25 a.g.e., s. 28. 
bir çeşit oryantalizm anlayışı ortaya çıktı. ${ }^{26}$ Fransa' da tatbik edilen bu tür oryantalist çalışmaların, sonraları İngiltere ve diğer tüm sömürgeci ülkelerde de büyük bir rağbet gördüğü ve desteklendiği görülmektedir. ${ }^{27}$ Bununla da, zaman içerisinde teorik boyutta sistemini oluşturarak bağımsız bir akım haline gelecek olan "uygulamalı" oryantalizm (angewandte oryantalistik)'in temelleri atılmış oldu. Şu halde Batı'nın Müslüman ülkelerdeki sömürge faaliyetlerinin bu akımın başlamasında doğrudan bir etkisinin olduğunu söylemek mümkündür. ${ }^{28}$

\section{Uygulamalı Oryantalizm Akımının Gelişim Süreci}

Yukarıda, Napolyon'un askeri seferlerine devamlı surette oryantalistlerden oluşan bir topluluğu da dahil ettiğini söylemiştik. Onların görevi, İslam coğrafyası ve Müslümanlar hakkında yerinde araştırmalar yapmak ve bunları sömürge güçlerine sunmaktı; bu araştırmaların sonuçlarını onlar, Becker'in dediği gibi, devletin bizzat "yazar bir memur"u (schriftstellender Beamter) ${ }^{29}$ ya da kendisi gibi "İslam sorununu politik bir mesele olarak"30 gören bir politikacı olarak uygulama durumunda değillerdi. Şu halde bu çalışmaları yürüten oryantalistler her ne kadar çalışma ve araştırmalarının sonucunda mevcut yayılmacı ve askeri politikayı desteklemeye yönelik eserler veriyorsalar da, onlardan, zikredilen bu politikayı devlet memuru ya da politikacı olarak doğrudan uygulayanlar henüz çıkmamıştı. Ancak bu durum, takriben 19. yüzyılın ikinci yarısından (1850'den sonra) itibaren değişmeye başlamıştır. Bu değişimin altında şüphesiz ki, iki önemli ismin imzası vardır. Bunlar, “... Teorik bilginin stratejik bir önem kazandığı bir dönemde..." 'Alman oryantalist derneği (Deutsche morgenländischen Gesellschaft)' ni kurmak suretiy$1 \mathrm{e}^{31}$, uygulamalı ya da siyasal/politik oryantalizm akımının gelişmesine en büyük katkıyı sağlayan, ${ }^{32}$ sömürge idaresinde uzun yıllar devlet memuru olarak çalışmış Hollandalı C. Snouck Hurgronje (1857-1936) ve Hitler döneminin Prusya Kültür Bakanı olan, meşhur Alman müsteşriki C. H. Becker (1876-1933)'dir. Bu tarihten itibaren oryantalistler artık sadece bilimsel araştırma ve incelemelerde bulunmuyorlardı; onlar aynı zamanda bazen

\footnotetext{
26 Heine, a.g.e., s. 28

27 a.g.e., s. 29.

28 Krș., a.g.e., s. 28., Watt, a.g.e., s. 34.

29 Hanisch, a.g.m., s. 111.

30 Becker, "İslampolitik", s. 310; "Staat und Mission in der İslamfrage", s. 211.

31 Hanisch, a.g.m., s. 109, dipnot 13. (Bu derneğin İstanbul'daki şubesi (Zweigstelle von DMG) 1928'de açılmıştır.)

32 Watt-Welch, a.g.e., s. 34.
} 
önemli kademdeki devlet memuru, bazen de hükümetin bir bakanı olarak devlet politikalarını ve siyasetini yönlendiren ve yöneten kişiler durumundaydilar.

İşte bu durum, yani oryantalistlerin siyasal ve politik amaçlarla yaptıkları oryantalizm çalışmalarını devlet memuru ya da politikacı olarak bizzat uygulama sahasına koymaları, uygulamalı oryantalizm'in en önemli özelliği olarak karşımıza çıkmaktadır; ${ }^{33}$ yani yerine getirdikleri görevin niteliğiyle doğru orantılı olarak, ürettikleri eserlerin niteliği de değişmiştir; daha ziyade hâkim politikayla paralellik arz eden ve onu destekleyecek türde, Müslümanların dili, tarihi ve inançları (teoloji) üzerine araştırma ve çalışmalar yürütmekteydiler. Buradan da anlaşılacağı üzere, Batının yayılmacı siyaset anlayışının ayrılmaz bir parçası olan uygulamalı ya da politik oryantalizm anlayışı, oryantalizm çalışmalarında temelde iki önemli değişiklik yapmıştır. Bunlardan birincisi, oryantalizm çalışmalarını yürüten oryantalistlerin, bu çalışmaları yapma gaye ve hedeflerinde, yani onların kimliklerinde, diğeri ise, bu birincisine bağlı olarak, yaptıkları çalışmaların yapısında yeni bir anlayış getirmiştir. Şimdi bunları detaylı olarak açıklayacağız:

\subsection{Bilim Adamlığından Politikacılığa/Teoriden Pratiğe (Uygulamaya)}

Bir bilim adamından beklenen, her şeyden önce, yapmış olduğu çalışmalardan elde ettiği verileri, bilimselliğin objektif doğasına uygun olarak, bilimin ve insanlığın hizmetine sunmasıdır. Tarihin her döneminde düşünürlerin ve bilim adamlarının (bunlara din alimleri de dahildir) "politik alanla ve politikayla yoğun bir ilişkisi olmuştur." ${ }^{4} 4$ Bu ilişki daha çok, "...kendi yetenek ve becerilerini içinde bulundukları devrin politik taleplerine uygun hale getirme, siyasal otoriteye danı̧̧manlık yapma" ${ }^{35}$ şeklinde gerçekleşmiştir. Kur'an'da, Mısır Kralı'na atfedilen şu sözler de muhtemelen bu duruma işaret etmektedir:

“...Ey ileri gelenler, siz eğer rüya yorumluyorsanız, rüyamın çözümü hususunda bana bir fetva verin."”6

Yukarıda zikredilen ayette geçen, "Yâ mele'u” (Ey ileri gelen/seçkin fikir/bilim adamları!) ve "Eftûnî fî rü'yâyâ" (rüyam hakkında bana bir fetva, bir fikir veriniz) ifadelerinden, Mısır hükümdarının, dini meselelerin çözümünde başvurduğu, “...içinde meşhur bilginlerin ve hikmet sahibi kimsele-

33 Hanisch, a.g.m., s. 107-108.

34 Ahmet Cevizci, "Politika ve Filozoflar", Felsefe Sözlüğü, Beşinci Baskı, İstanbul 2002, s. 832.

35 a.g.y.

36 Yûsûf Sûresi, 12: 43 
rin de bulunduğu..." ${ }^{37}$ bir "danışma meclisine" 38 sahip olduğuna işaret etmektedir. Ancak burada dikkat edilmesi gereken husus, tarihin hemen her döneminde bilim adamları ve siyaset/siyasetçiler arasında gerçekleşen sözü edilen bu ilişkide, her ne kadar siyaseti ve siyasetçileri zaman zaman kendi düşünceleri doğrultusunda etkilemeye çalışıp, buna yönelik kararlar aldırmaya çalışmışlarsa da, bilim adamlarının yetkisinin çoğunlukla, sadece "danışılma" ve "bilgi edinilme" yle sınırlı kaldığı, sorunların çözülmesinde bizzat "uygulayıcı" bir konumda olmadıklarıdır. İşte 'uygulamalı' oryantalizm akımı, yukarıda açıklamaya çalıştığımız, bilim adamlarının bu kimliklerinin/yapılarının değişmesinde önemli bir etki yapmıştır. Bu tür bir oryantalizm anlayışında, oryantalist çalışmalarının doğrudan politik gayelerle ve bizzat bilim adamı kimliğini taşıyan politikacılar tarafından yapılması gelenekselleşmiştir. ${ }^{39}$ Yani, bu akımla birlikte oryantalistler, bilim adamı olma özelliklerinden daha ziyade, devlet memuru yahut siyasetçi olmalarıyla ön plana çıkmışlardır.

Alman İslam bilimcisi (İslamwissenschaftler) Peter Heine ${ }^{40}$, esasen her bilim adamını böyle bir tehlikenin beklediğini ve bundan sakınılması gerektiğinin altını çizdikten ${ }^{41}$ sonra, uygulamalı oryantalizm çalışmalarının yapılış gayesi hakkında bizlere bazı ipuçları vermektedir. Ona göre bunda birinci etken, sözü edilen sahanın tabiatı gereği buna oldukça olanaklı olmasıdır. Zira, oryantalizm araştırmaları, uygulamalı/tatbiki bilimler (anwendungsbezogene oder angewandte Wissenschaft; İng. applied science) grubuna dahildir. Bilindiği üzere, uygulamalı bir disiplin “...salt düşünce ve teoriyle ilgili olmayıp, pratikle de ilgilenmesi, hayatın somut problemlerine yönelmesi, somut deneyimin çeşitli veçheleri için çözüm üretmeye kalkışması..."42 yönünden diğer disiplinlerden ayrılmaktadır. Uygulamalı ya da politik oryantalizmin pratikte uygulandığ saha da politika ve siyaset olduğuna göre, bu sahada ilmi faaliyet gösteren herhangi biri, elde ettiği bilimsel verilerle, kendisini kolayca politik tartışmaların, dolayısıyla da politikanın ortasında bulabilir. $^{43}$

37 Elmalılı M. Hamdi Yazır, Hak Dini Kur'an Dili, (sadeleştirenler: İsmail karaçam, Emin Işık, Nusrettin Bolelli, Abdullah Yücel, Mahmut Özakkaş), İstanbul Tarihsiz, c. 5, s. 46.

38 a.g.e. , s. 46.

39 Bkz., Hanisch, a.g.m., s. 111.

40 Prof. Dr. Peter Heine (d. 1944). Humboldt Üniversitesi, Felsefe Fakültesi Asya ve Afrika bilimleri Enstitüsü İslam Bilimleri Bölümü Başkanı.

41 Heine, a.g.m., s. 387.

42 Cevizci, "Uygulamalı" maddesi, a.g.e., s. 1061.

43 Heine, a.g.m., s. 387. 
Özellikle 19. yüzyılın başından itibaren Batılı devletlerin Müslüman ülkelerde giriștiği sömürgecilik faaliyetleri, yöneticilerle oryantalistler arasında sıkı bir ilişkinin doğmasına sebep teşkil etmiștir. Yukarıda da açıkladı̆̆ımız gibi, Napolyon'un Mısır'ı işgal etmesiyle başlayan bu sürecin başlang1cında, sadece "bilimsel lojistik destek" düzeyinde kalan bu ilişki, sonraları daha da gelişmiş ve en sonunda oryantalistlerin önce sömürge bölgelerinde devlet adına çalışan devlet memuru, daha sonra ise bizzat politikacı olmaları sonucunu doğurmuştur. Bu akımın hâkim olduğu dönemde birçok oryantalist sırf politik gayelerle eserler vermiştir. Bunların başında, Heine'ye göre bu akımın kurucusu ve Becker'in öncüsü durumunda olan, Hollandalı meşhur oryantalist C. Snouck Hurgronje (1857-1936)'yi zikretmek gerekir. Aslında ona göre Hurgronje'den önce de, örneğin1870/71 Alman-Fransız savaşında, oryantalizm çalışmalarını Almanya'nın askeri çıkarları yararına kullanma girişimleri mevcuttu. ${ }^{44}$ Ancak Hurgronje'yi belki de uygulamalı/ politik oryantalizm akımının ilk temsilcisi konumuna getiren, oryantalizm tarihinde "oryantalizm çalışmalarını sırf politik ve siyasal gayelerle yürütmesi" için doğrudan devlet memurluğu makamına getirilen ilk kişi olmasıdir. ${ }^{45}$

Hurgronje, 17 yıl boyunca Hollanda'nın Endonezya'da ki koloni dairesinde çalışmış ve araştırmalarını bu süre boyunca devamlı surette, 'Hollanda Sömürge İdaresi' için yürütmüştür. ${ }^{46}$ Yani onun, Endonezya'da İslam ve Müslümanlar üzerine yaptığı teorik çalışmaların niteliği, bu idarenin 'pratikte' yani 'uygulamada' ki gereksinimlerine göre şekillenmiştir; Endonezya sömürge bölgesini yöneten bu idare, ihtiyaç duyduğu konularda, araştırma yapması hususunda Hurgronje'yi görevlendiriyor o da bu konularda araştırma yapıyor, daha sonra bunları yönetime sunuyordu. Onun araştırmalarından elde edilen veriler yukarıda da açıklandığı üzere 17 yıl boyunca Hollanda'nın Endonezya sömürge bölgesinde yürüttüğü siyaseti doğrudan etkilemiştir. Zira, bir çok konuda eser vermesine karşın, bunlardan en önemlileri, "İslam'ın çağdaş görünümleri ve yansımaları" (zeitgenössiche Erscheinungsformen) üzerine olanlarıdır. ${ }^{47}$ Bu eserlerin önemi, pratik hayattan gözlemler yapılmak suretiyle, yine bizzat pratik hayatta tatbik edilmek üzere ortaya konulmalarından ileri gelmektedir. Bir başka deyişle bu eserlerin, sömürge bölgelerinde Hollanda'nın çıkarlarını korumak için, gerçek hayatta

44 Bkz. Heine, "Das Rohlfs-Wetzstein-Unternehmen İn Tunis während des deutsch-franzözischen Krieges, 1870/71", In: Die Welt des İslams, NS, Bd. 22/1982, s. 61 ff.

45 Heine, a.g.e., Berlin 1989, s. 30.

46 J. J. Waardenburg, L'islam dans le miroir de I'Occident, Paris 1963, s. 20/21. Heine, a.g.e., s. 30. 47 Watt-Welch, a.g.e., s. 34. 
"uygulanabilir bir fonksiyonu" (anwendungsbezogene Funktion) ${ }^{48}$ vard1. Bu yüzden Hurgronje, görev süresince, Endonezya'nın en karmaşık ve asayişi bozuk bölgesi olan Atjeh'i tercih etmişti. O, bu huzursuzluk ve kargaşanın arkasında yatan olası, dilsel, tarihsel ve teolojik nedenleri tespit etmek amacıyla bizzat yerinde gözlemler yaparak veriler topluyor, bir bilim adamı (oryantalist) olarak elde ettiği verileri analiz ediyor, bu analizlerin sonunda nedenleri tespit ediyor ve alınacak tedbirlerin ve uygulamaların nasıl olmas1 gerektiği hususunda rapor sunuyor, zaman zaman da bu uygulamaları bizzat kendisi yürütüyordu. ${ }^{49}$

\subsubsection{Becker Dönemi Uygulamalı Oryantalizm}

Şu halde, Hurgronje ile birlikte, bu akımın ortaya çıkardığı birinci unsur olan "bilim adamlığından politikacılığa yani teoriden pratiğe, başka bir deyişle düşünceden uygulama'ya" geçişin gerçekleşmeye başladığı açıkça görülmektedir. Ancak Heine'ye göre sözü edilen uygulamalı oryantalizmin en önemli temsilcisi, Hurgronje'den oldukça etkilenen ${ }^{50}$, Carl Heinrich Becker (1876-1933)'dir. ${ }^{51}$

Onu bu yargıya götüren etkenler şunlardır: ${ }^{52}$

1. Becker, oryantalizm çalışmalarında takip ettiği metodu, öncüsü durumunda olan C. Snouck Hurgronje'dan almış ve bunu daha da sistematik bir hale getirmiştir.

2. Prusya Kültür Bakanı olduktan sonra, oryantalizm çalışmalarının politik-siyasal amaç ve gayelere hizmet etmesi ilkesini bir hükümet politikası haline getirmiştir.

Gerçekten de Becker'in yapıp-ettikleri göz önüne alındığında, Heine'nin yukarıda açıkladığımız iddiasında, esasen pek de haksız olmadığı gözlenmektedir. ${ }^{53}$ Şimdi onun uygulamalı oryantalizm anlayışından ne anladığını açıklayacağı:

1. Becker'e göre İslam, sadece dini bir mesele değildir: O, oryantalizm çalışmalarında şu ana kadar hakim olan unsurun, olgu ve olaylara tek taraflı, yani sadece dinsel pencereden bakmak olduğunu ortaya koymaktadır:

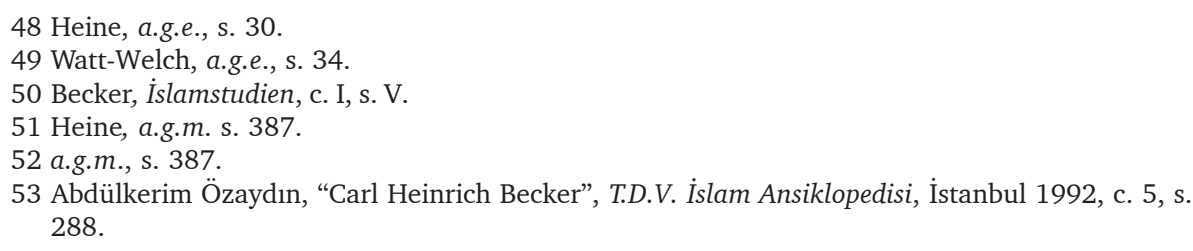


"İlam problemi, çoğunlukla dini bir mesele olarak değerlendirilmektedir, oysa İslam sadece bir din değil, ayn zamanda bir medeniyet ve siyasal bir düşüncedir (Staatsgedanke)..."

Ona göre, İslam'ı sadece dini bir mesele olarak değerlendirenlerin başında Goldzieher ve Nöldeke gelmektedir. Bunu, bu ikisi, Becker ve Hurgronje arasında gerçekleşen mektup yazışmalarından anlamaktayız. ${ }^{55}$ Becker, Alman devlet yöneticilerine bir tür tavsiye niteliği taşıyan, "Staat und Mission in der İslamfrage (İslam meselesinde Devlet ve Misyon)" "56 adlı makalesinde bu hususa bir kez daha vurgu yapar:

“...Sömürgelerimizde, daha kısa süre öncesine kadar, İslam'n sadece, ilettiği mesajlarla (Missionen) alakadar olundu...Hatta en son düzenlenen sömürge kongresinde bile İslam meselesi sadece zikredilen bu misyon düşüncesi temsilcileri (misyonerler) tarafindan ele alınıp değerlendirildi. Onların yöntemleri genel olarak büyük bir kabul gördü. İşte, misyonerlerin oldukça değer verilen bu yöntemlerinin oldukça sakıncalı bir sonucu olarak, İslam meselesi sadece "dini bir mesele" olarak kabul edildi..." "57

Ancak o, meseleye tek açıdan bakmanın büyük bir hata olduğunu, bunun da başarısızlıkla sonuçlandığını belirtir:

“...Ancak bunun, birakın meseleyi çözmesini, daha da karmaşık bir hale getirdiği bile söylenebilir; zira misyonerlerin takip ettiği metot ile politikacıların takip etmek istedikleri siyaset arasındaki uçurum daha da fazlalaştı...Misyonerlerin takip ettikleri metot, temelde, sömürgelerin tamamen Huristiyanlaştırılması esasına dayanmaktaydı. Onlar sorunun bu şekilde çözüleceğine inanmaktaydılar... Oysa sorunun bu şekilde çözülmesi adeta imkansızdır, zira bunu daha önceleri sömürgecilik konusunda bizden çok daha uzman olan İngilizler, Fransızlar ve Hollandalılar denemişler, ancak bunda başarılı olamamışlardır..." 58

2. İslam aynı zamanda ve daha çok politik bir meseledir: Becker'e göre, inançlarına oldukça bağlı olan Müslüman sömürgelerde yaşayan halkın yönetilmesinde ciddi problemler ortaya çıkaran ve onları dinlerinden döndürme temeline dayanan bu anlayışın modası geçmiştir ve bunun artık değiş-

54 Becker, "İslampolitik”, İslamstudien, Bd. II, Leipzig 1932, s. 310.

55 Bu mektuplar için bkz., P.S. Van Koningsveld, Orientalism and İslam-The Letters of C. Snouck Hurgronje to I. Goldzieher, Leiden 1985, s. 147-173, 186, 191; Ròbert Simon, Ignâc GoldzieherHis Life and Scholarship as Reflected in His Works and Correspondence, Leiden 1986, s. 76, 187, 258, 282, 334; Hanisch, a.g.e., 114-123.

56 Bu makale 1910 yılında kaleme alınmış, aynı yılın 6 Ekim’inde Alman Koloni Kongresinde sunulmuş ve 1932 yılında da yayınlanmıştır (İslamstudien, Bd. II, Leipzig 1932, s. 211-225).

57 Becker, a.g.m., s. 211

58 Becker, a.g.m., s. 211-215. 
mesi gerekmektedir: Zira ona göre, yukarıda da ifade ettiğimiz gibi, İslam meselesi dini olmaktan daha çok politiktir:

“...Bundan dolayı da İslam meselesini dâhili ve harici politik bir mesele olarak görmek daha anlamlı ve isabetli olacakttr." 59

"İslam meselesi her şeyden önemli politik bir koloni/sömürge meselesidir, bu da Almanya'nın sömürgelerinde uygulamaya konulacak her türlü politiksiyasal önlemin, İslam'a yapacağı etkisi derecesinde değerlendirilmesi gerçeğini ortaya koymaktadır. İslam meselesinin varlı̆̆l, yönetim kademelerinde bilinçli bir İslam politikasının oluşturulmasını gerektirmektedir. Hükümet bu gerçeğin farkındadır. Ancak bu her zaman böyle olmamıştır..."..."60

Becker, bu tespiti yaptıktan sonra, meselenin çözümünde uygulanacak yeni politikanın çerçeve şartlarını ortaya koymaktadır. Bunlar şu şekildedir:

a. Müslümanlarla uzlaşma çabalarına girişilmesi

“... Bu politikanın temel amacı, Müslümanları Huristiyanlaştırmak değil, olsa olsa onların sahip oldukları değerleri Avrupalılaştırmak, böylece de onları daha iyi sevk ve idare etmek olmalıdır. Misyonerlerin takip ettikleri yöntemin, zaman zaman bu hedefin gerçekleştirilmesinde engel olduğu görülmektedir. Zira onlar takip ettikleri bu yöntemle sömürge topraklarında sık sık Müslümanların ayaklanmalarına sebebiyet vermektedirler... Oysa yukarıda zikredilen devletler daha sonra bu politikalarından vazgeçmişler ve sorunu, İslam ve Müslümanlarla işbirliğine girmek suretiyle çözmeye çalışmışlardır. Bu metot o kadar etkili olmuştur ki, bugün Hindistan'da İngilizlerin en büyük destekçileri Müslümanlardır..."61

b. Görüldüğü üzere bu uzlaşı ve işbirliği, Batı'nın çıkarlarının korunması ve sürekliliğ̈i için yapılmıştır. Ancak bunun uzun vadeli olması için bazı adımlar atılmalıdır; bunların başında ise Müslüman sömürgelerde yaşayanların Avrupa eğitim sistemiyle yetiştirilmeleri gereklidir:

“...Bu politika, aynı zamanda, İslam'ın, biz Avrupalılara tehdit oluşturabilecek fanatik ve aşırı yönlerinin ortadan kaldırılmasını da içermelidir. Bu da ancak Müslüman sömürgelerde, Avrupa eğitim sisteminin uygulanmastyla mümkün olacaktır..."62

Ancak, verilecek eğitimin başarıya ulaşması, büyük ölçüde, sömürgelerde ve onlara her yönden tesir edebilecek durumda olan Osmanlı idaresinde yaşamış Müslümanları, dilleri, kültürleri ve inanç sistemleriyle tanımayla, bir başka deyişle Müslüman coğrafyanın inanç haritasının çıkartılmasıyla

59 Becker, "İslampolitik", s. 310.

60 Becker, "Staat und Mission", s. 211.

61 a.g.m., s. 215.

62 a.g.m., s. 215. 
doğru orantılıydı; yani isabetli bir İslam politikası için teorik bilgilerin elde edilmesi kaçınılmaz hale gelmişti. ${ }^{63}$ Oysa bu araştırmaları yapacak yeterli sayıda araştırmacı yoktu. Bu eksikliğin bir an önce giderilmesi bu politikanın başarısı için oldukça önem arz etmekteydi:

“...Bunun gerçekleşebilmesinin önündeki en büyük engel, dinlerine ve geleneklerine oldukça bağlı olan bu insanların sahip oldukları inanç ve düşünceler konusundaki araştırmaların oldukça eksik olmasıdır. Bu konudaki eksiklik bir an önce giderilmelidir. Bu da insicamlı bir İslam politikasının varlığıyla aşılabilir... Oysa yukarıda da anlatıldı̆̆ üzere, Müslümanların, bize göre sahip olduklart tehlikeli değerler, Avrupa eğitim sisteminin yerleştirilmesiyle kısa sürede ortadan kaldırılabilir. Yeter ki, yukarıda sözü edilen, onların kültür ve gelenek birikimlerinin oluşturduğu inanç sistemleri konusunda araştırmalar yapılsın ve bu araştırmalar üzerine kurulu okul eğitimi oluşturulsun... Okul eğitimi konusuna oldukça fazla önem vermekteyim. Zira İslam ancak Avrupa kültürü temelinde verilecek bir eğitimle bizim için tehlike olmaktan çıacaktır..." 64

İşte Becker düşüncesi, bu sorunu aşmak için yeni bir formül ortaya attı. (Aslında bu, Fransa'nın Mısır'ı işgalinden beri uygulanmaktaydı; ancak onunla birlikte bu kural önemli bir ilke haline geldi). Bu formüle göre her oryantalist devlet siyasetinin uygulanmasında aktif rol almalıdır. Bu ilke, bir yanda yürütülen politikanın hızlı bir şekilde uygulanması için ihtiyaç duyulan teorik düzeydeki bilgilerin kısa sürede elde edilmesini sağlarken, diğer yanda ise oryantalizm çalışmalarının doğrudan siyasallaşması sürecine neden olmaktaydı. ${ }^{65}$

Becker'e göre bu iş için desteklenecek araştırmacıların iki belirleyici özelliği olacaktır:

1. Onlar, devletin takip ettiği siyasete araştırmalarıyla katkı sağlayan, bir nevi "yazar memur" (schriftstellernder Beamter) konumundadırlar, bu yüzden de istedikleri konularda değil kendilerinden istenilen konularda araştırma yapacaklardır. ${ }^{66}$

2. Desteklenen araştırmacılar İslam ülkelerindeki kütüphanelerde çalışarak buralardaki önemli yazma eserlerin kataloglarını hazırlayacaklar, gerektiğinde bunları Almanya'ya kazandıracaklardı. Onlar bu sayede "Müslüman Doğu'yu bizzat ilim seyahatleri ve kütüphane ziyaretleriyle tanımış olacaklardı."

63 Hanisch, a.g.m., s. 109, dip not 13.

64 a.g.m., 215-225.

65 Heine, a.g.m., s. 387.

66 Hanisch, a.g.m., s. 111. 
Bu iki husus, Becker tarafından 1904 yılında formüle edilmiştir: Onun bununla ulaşmak istediği hedef şuydu: Devletin memuru konumundaki İslam ve Doğu üzerine araştırma yapan bilim adamları (oryantalistler), İslam ülkelerini ve Doğu'yu artık sadece kitaplarla, yani teoride değil, "uygulamalı" ya da "siyasal" oryantalizm anlayışının bir gereği olarak, bizzat buralara gitmek suretiyle pratikte, bir başka deyişle gerçek hayatta öğreneceklerdi. Bu da onların, devletin hali hazırda Müslüman ülkelerde takip edeceği İslam politikasının nasıl olması gerektiğine dair yapacakları araştırmalara malzeme toplama açısından önemli katkılar sağlayacaktır. ${ }^{67}$

$\mathrm{Bu}$ tür bir oryantalizm anlayışına sahip olan Becker bu amaçlarını gerçekleştirmek için önemli bir fırsat elde etti; bu da 1907'de sömürgeci siyaseti desteklemek amaciyla kurulan ${ }^{68}$ iki enstitüden biri olan Hamburg'daki Koloni Enstitüsü (Hamburger Kolonialenstitüt) 'nün 'Ön Asya Kültürü ve Tarihi' (Geschichte und Kultur des vorderen Orients) bölümünün müdürlüğüne atanmasıydı. ${ }^{69}$ (Bu enstitülerden diğeri ise Berlin'de 'Seminar für orientalische Sprachen' "Doğu Dilleri Bölümü" idi. Bu enstitünün müdürlügü̈ne de Ernst Schau getirilmiştir). 1913 yılına kadar bu görevini sürdürdü. Bu süre içerisinde düşünceleri doğrultusunda öğrenciler yetiştirdi. (Ancak o, temsil ettiği bu anlayışıyla bilimsel çevrelerden zaman zaman, 'aşırı bir milliyetçi politikası gütmekle ${ }^{70}$ itham edilmiş bunun sonucunda da derin tartışmalar yaşanmıştır. ${ }^{71}$ ) Bu çalışmalarında başarılı bulunmuş olacak ki, 1916 yılında Prusya Kültür Bakanlığı'nda raportör olarak çalışmaya başlad1. ${ }^{72} 1921$ ile 1930 yılları arasında aralıklarla Kültür Bakanlı̆̆ı yaptı. ${ }^{73}$ Böylece o, Bakanlığı süresince, oryantalizm anlayışının gerçekleşmesi yönündeki adımları artık bizzat bir siyasetçi olarak yürütecektir.

Becker, tesiri altında kaldığı oryantalizm anlayışına bağlı olarak, Almanya'nın sömürgelerinde ve bu sömürgeler üzerinde oldukça etkili olan Osmanlı İmparatorluğu ve o yıkıldıktan sonra da Türkiye Cumhuriyeti'nde yaşayan halkın inanç sistemini oluşturan temel öğeler üzerinde araştırmaların yapılmasına ve elde edilen verilerin, bu politikaya uygun olarak pratiğe dökülmesine oldukça önem vermişti. Ona göre, sömürge elde etmede oldukça geç kalan Almanya bu sayede hem İslam ülkelerinin önemli bir

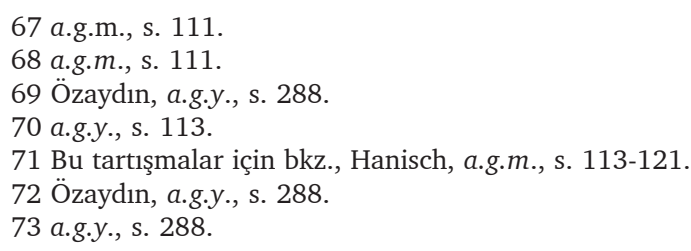


bölümünde nüfuz sahibi olabilir, hem de İslam kültür mirasıyla ilgili el yazmalarının merkezi konumuna yükselebilirdi. Bu iki husus da, Almanya'yı diğer Batılı ülkelerden bir adam daha öne geçirebilirdi. ${ }^{74}$

Becker'in temsil ettiği Prusya Kültür Bakanlığı işte bu amaçları gerçekleştirmek için birçok oryantalisti, başta İstanbul olmak üzere, İslam ülkelerinin önemli kütüphanelerinin bulunduğu bölgelere gönderdi. Onların görevi bu kütüphanelerindeki el yazmalarını ortaya çıkarmak, edisyon kritiğini yapmak, yayımlamak ve en son olarak da bunları Almanya'ya taşımaktı. ${ }^{75}$ Ancak yukarıda da açıklandığı üzere gönderilecek araştırmacılar (oryantalistler) devletin kadrolu memurları olacağından, ilgi duydukları konulardan daha ziyade, yukarıda zikredilen amaçlara uygun olarak çalışmayı kabul ettikleri takdirde burs alabileceklerdi. İşte bu oryantalistlerden biri de Becker'in asistanlığını yapan (1913-1914) meşhur Türkolog ve oryantalist Hellmut Ritter (1892-1971)'dir. Ritter'in akademik hayatı, 'uygulamalı oryantalizm' akımının hakim olduğu süreçte, siyasetle bilim adamı (oryantalist) arasındaki ilişkiyi ortaya koyması açısından iyi bir örnek teşkil etmektedir. Şimdi buna kısaca değineceğiz:

Hamburg Üniversitesi'nde görevine son verilen Ritter, esasen kendi çalışma sahası olan, Fars Dili ve Edebiyatı üzerinde çalışmalar yapmak istediği İran'a gitmek üzere burs talebinde bulunur. ${ }^{76}$ Ancak, Prusya Kültür Bakanlığı, yukarıda sıralanan hedefleri gerçekleştirecek araştırmacılar dışında kimseye burs vermek istememektedir. Bunun doğal bir sonucu olarak da, kendisine ancak, İstanbul'a gitmesi karşılığında burs verilebileceği bildirilir. İşsiz olan Ritter de bu teklifi kabul etmek zorunda kalmıştır. ${ }^{77}$ Ancak bu görevi kabul ederken söylediği sözler oldukça dikkate şayandır. Bu sözler, maddi imkanı olmayan bilim adamlarının burs karşılı̆̆ında sözü edilen politik gayelerle nasıl kullanıldığına önemli bir örnek teşkil etmektedir. Bunları Ritter, Becker'e yazdığı bir mektupta açıkça dile getirmektedir:

"Profesör Tschudi tarafindan bana önerilen bilimsel görev, itiraf etmeliyim $k i$, ilgi alanım dışında olduğundan beni pek tatmin etmedi... Bu görevle benden istenenin ne olduğu hususunda fazla bir bilgiye sahip de değilim... Benim ilgimi esasen İstanbul'dan daha ziyade İran çekmektedir."”s

Ancak görünen o ki, Ritter, bir şekilde Becker tarafından İstanbul'a gitmesi hususunda ikna edilmiş görünmektedir. Bunda muhtemelen en önem-

74 Thomas Lier, "Hellmut Ritter in İstanbul 1926-1949", Die Welt des İslams, Vol. 38, November 1998 (3), s. 335.

75 a.g.m., s. 338.

76 a.g.m., s. 334.

77 a.g.m., s. 334.

78 Ritter an Becker vom 27. 8. 1926, Hessisches Staatsarchiv Marburg, Nr. 345. 
li faktör, kendisine İstanbul kütüphanelerinde Fars dili ve edebiyatı üzerine yazılmış birçok el yazmasının olduğu, böylece de ilgilendiği konularda da çalışma yapabileceği konusunda garanti verilmesidir. ${ }^{79}$ Oysa verilen bu garantinin İstanbul'da Hellmut Ritter'e bir fayda sağlamadığı açıkça görülmektedir. Zira o, İstanbul'da kendi çalışmalarından daha çok, kütüphanelerde bulunan yazma eserlere kendini adamıştır..."

Ancak başlangıçta bu durumdan rahatsız olan Ritter, Alman çevrelerinde adeta milli bir politika haline gelen bu anlayışı zamanla benimsemiş ve yazdığı raporlardan da da anlaşılacağı üzere, bunun mutlak bir savunucusu haline gelmiştir:

"Ancak İstanbul'da bir süre kalan her oryantalistin ilk ödevi, oradaki mevcut kütüphanelerde meşgul olmaktır. Bu iddiamı temellendirmek için şunu söylemem mümkündür: İstanbul'un takriben 60 kütüphanesinde bulunan el yazmaları hazinesinin \% 50-60' ^ Avrupalı bilim adamlarınca bilinmemektedir. (...) Bunun sebebi şudur: Kütüphanelerin kataloglarının sadece bir kısmı Avrupa'da bulunmaktadır, bunların ise çok azı Almanya'da mevcut olup, bunlar hakkındaki bilgiler büyük oranda yanlıştır. (...) Bu kataloglar her ne kadar Brockelmann'ın 'Arap Literatür Tarihi' adlı eserinde kullanılmış olmasına rağmen, buradaki şaşkınlığımı tespit etmem gerekir, bu, yazma eserlerin özetlerinin kullanılmasindan (auszugsweise) öteye geçememiştir.(...)

Burada bulunmamın ikinci hedefi ise, Avrupa oryantalizmi için bir tür araculık rolü üstlenmektir; zira böyle bir rol olmaksızın İstanbul kütüphanelerinde bulunan el yazmaları hakkında bilgi edinme isteği boşa çıkacaktır. (...) Burada kalmam hususunda bana şayet gereken kolaylıklar gösterilip, bunun için imkânlar sunulursa, bunun sonucunda, gelecekte Avrupalı her bilim adamı, ihtiyaç duyduğunda, buradaki kütüphanelerdeki mevcut el yazmalarının negatif fotoğrafların benden temin edebileceklerdir..."

Görünen o ki, Ritter başlangıçta isteksiz olarak geldiği İstanbul'da kanaatini bir şekilde değiştirmiş, başta hocası C.H. Becker olmak üzere, birçok Alman oryantalistin gerçekleşmesi hususunda gayret ettikleri ve adeta aşırı Alman milliyetçiliğiyle özdeşleşmiş olan "uygulamalı oryantalizm" anlayış1nın savunucusu ve bizzat Türkiye'deki uygulayıcısı olmuştur.

Yukarıda da belirtildiği üzere, bu anlayışın temsilcileri durumundaki oryantalistlerin en önemli özelliklerinden birinin, aşırı Alman milliyetçileri

79 Bkz., "Bericht über meine wissenschaftliche Tätigkeit in Konstantinopel im Winter 1926/27 von Hellmut Ritter", Dr. Phil., Hessisches Staatsarchiv Marburg, Nr. 345.

80 Lier, a.g.m.,s. 334.

81 "Bericht über meine wissenschaftliche Tätigkeit in Konstantinopel im Winter 1926/27 von Hellmut Ritter", Dr. Phil., Hessisches Staatsarchiv Marburg, Nr. 345. 
olmaları ve çalışmalarını Almanya'nın politik gayeleri için yürütmeleri olduğu ileri sürülmüştür. ${ }^{82}$ Ritter'in yaptığının da bundan başka olmadığı iddia edilmektedir: Zira, Türk basınında, Ritter'in, Becker'in Prusya Kültür Bakanlı̆̆ı'ndan ayrılmasından sonra görevden alınmasının nedeni olarak, "Alman sosyalist milliyetçilerine karşıtlığı" olduğuna dair haberler çıkmıştır. ${ }^{83}$ Her ne kadar bu haberler Alman Arkeoloji Enstitüsü (DAI), ve Alman konsolosluğu tarafindan kesin bir dille yalanlanmısssa da ${ }^{84}$ bu haberlerden hemen sonra onun tekrar görevine iade edilmesinin bu iddiaları desteklediği ileri sürülmüştür. ${ }^{85}$ Ayrıca Ritter'in gerek burslu gerekse idari görevle İstanbul'da bulunduğu süre içerisinde yaptığı çalışmaların gaye ve hedeflerine dair verilen raporların sözü edilen iddialarla paralellik arz ettiği görülmektedir. ${ }^{86}$ Bunlardan, özellikle 1933'de sona eren görevinin uzatılması hususunda Prusya Kültür Bakanlığı'na yazılan raporu, tüm bu yukarıda söylenenleri aydınlatıcı mahiyette olması açısından oldukça önemlidir:

“...Biz Almanya'da, İngiltere'deki Britisch Museum'da olduğu gibi, bilimsel kaynaklara sahip değiliz. Ancak bizzat Hellmut Ritter'in bitmez tükenmez çalışmaları sayesinde İstanbul kütüphanelerinin zengin hazineleri artık Almanya'nın malı haline gelmiştir." 87

Bu rapor, İstanbul kütüphanelerinde bulunan değerli birçok yazma eserin nasıl ve ne şekilde yurt dışına çıkarıldığını göstermekle kalmayıp, yukarıda da belirtildiği üzere, Hitler döneminin Alman milliyetçiliğinin ayrılmaz bir parçası olan "uygulamalı oryantalizm" e Hellmut Ritter'in yaptığı katkıların ne kadar önemli olduğunu da açıkça ortaya koymaktadır. Zira, Becker'in, takip ettiği bu siyasetle hedeflediği iki husustan biri olan "Almanya'nın İslam kültür mirasıyla ilgili el yazmalarının merkezi konumuna yükseltilmesi", bu raporda da belirtildiği üzere, büyük ölçüde Ritter’in çalışmaları sayesinde gerçekleşmiştir. Onun, Bittel'e yazdığı mektubunda "hiçbir partiye üye olmadım ve Hitler döneminde muhalifler arasında yer aldım..." demesi de, bize göre, bu gerçeği değiştirmemektedir. Zira bu mektup 2. Dünya savaşından sonra 16. 7. 1948 tarihinde İstanbul Bebek'te kaleme alınmış olup artık Hitler dönemi çoktan geride kalmıştır. ${ }^{88}$

82 Hanisch, a.g.m., s. 113.

83 Bkz., Son Posta, 13 Temmuz 1933.

84 Bu tekzibler 14 Temmuz 1933 tarihli Cumhuriyet Gazetesi’nde yayınlanmıştır.

85 Bkz., Lier, a.g.m., 348-349.

86 Bunlar için bkz., Lier, a.g.m., 345-350.

87 "Ritter'in İstanbul'daki çalışmalarıyla ilgili bilimsel rapor", München 8. 7. 1933, Hessisches Staatsbibliothek, Nr. 302. (Bu raporun ikinci sayfası eksik olduğundan kimin tarafından yazıldığ1 tespit edilememektedir)

88 Bittel'e gönderdiği mektuplar için bkz., Lier, a.g.m., s. 376-382. 


\subsection{Uygulamalı Oryantalizm'in Yapılan Çalışmaların Niteliğinde Yaptığı Değişiklik}

Yukarıda, bu yeni akımın oryantalizm'i iki açıdan etkilediğini söylemiştik; bunlardan birincisi, oryantalistlerin yapısında değiş̧iklik yaparak, onları, tamamen resmi politika için araştırma yapan, Becker'in ifadesiyle, "yazar memur" durumuna getirmesiydi. Bunu detaylı olarak anlattık. Uygulamalı oryantalizmin yaptığı ikinci etki ise, verilen eserlerin yapısındaki belirgin değişiklik olmuştur. Bunu biraz daha açacă̆ız:

Yayılmacı siyaseti destekleyen bu tür oryantalizm anlayışının en önemli özelliği, dil, tarih ve teoloji merkezli olmasıdır. ${ }^{89}$ Hatırlanacağı üzere, oryantalizm çalışmalarının ilk döneminde Müslüman Doğu üzerine yapılan çalışmalar, daha çok İslam dininin inanç sistemi yani teoloji; ikinci döneminde ise genellikle dil (filoloji) ekseninde yürütülmekteydi. ${ }^{90}$ Bu da bize, bu son dönemde yapılan çalışmaların, hedeflenen amaçların büyümesi doğrultusunda, ilk iki dönemi de kapsayacak şekilde daha da geniş bir sahaya yayıldığını göstermektedir. Ele geçirilen coğrafyayı ve bölge insanını, onun dili, tarihi ve inançları üzerinden tanımak, dolayısıyla da bunu askerî çıkarlar, yani sömürgeleştirilen toprakların daha da genişletilmesi, için kullanmak, bu dönemdeki oryantalizm çalışmalarının merkezinde yer almaktayd. ${ }^{91}$ Hedefler büyüyünce elbette ki, çalışmaların yoğunluğu ve kapsamı da buna paralel olarak genişlemekteydi. İşte, tüm bu sebeplerle, Bu dönemde verilen eserler de doğal olarak hakim politikayla paralellik arz etmek durumundaydı; Bu durum esasen Batılı sömürge güçlerinin bilinçli olarak geliştirdikleri bir siyasetin sonucu olarak karşımıza çıkmaktadır. Bu siyasetle onların ulaşmak istedikleri hedef, İslam ülkelerinin daha kolay sömürgeleştirilmeleriydi. ${ }^{92}$ Bunun gerçekleşmesi ise, yoğun bir şekilde gerek Müslümanların tarihi ve inançları, gerekse onların sahip oldukları Arapça kaynakları hakkında eleştirel bakış açısıyla, inceleme ve araştırmaların yapılmasına bă̆lıydı. Bu konularda büyük çalışmalar yapıldı Yapılan eserlerin bu özelliğinden dolayı oryantalizmin bu 'uygulamalı' dönemine "tarihsel-kritik dönem" (historisch-kritische Periode) ${ }^{93}$ adı da verilmektedir. Bu dönemi kısaca ele alacağız:

\footnotetext{
89 Hanisch, a.g.m., s. 110.

90 Heine, a.g.e., s. 21.

91 Heine, "Das Rohlfs-Wetzstein-Unternehmen İn Tunis während des deutsch-franzözischen Krieges, 1870/71", s. 61.

92 Heine, a.g.e., s. 28-30.

93 Watt-Welch, a.g.e., s. 28.
} 
Gustav Weil'ın 1843'de yazdığı "Mohammed der Prophet, sein Leben und seine Lehre" (Peygamber Muhammed'in Hayatı ve Öğretisi) adlı eseri bu bağlamda ilk örneği teşkil etmektedir. ${ }^{94}$ Bu eserin önemi, oryantalizm çalışmalar1 tarihinde "Müslüman-Arap kaynakları ve tarihi hakkında yapılan ilk eleştirel değerlendirme" 95 olmasından ileri gelmektedir. Ancak Weil'in, bu eseri yazarken dayandığı kaynakların oldukça geç döneme ait olması önemli bir eksiklikti ${ }^{96}$ : Zira, uygulamalı oryantalizmin ana ilkelerinden biri, Müslümanların tarihini ve inançlarını doğrudan Müslüman ülkelerdeki kütüphanelerde bulunan ilk yazma eserlerden öğrenmekti; bu, onlarla ilgili daha isabetli bir siyaset anlayışı geliştirmenin en etkili yoluydu. ${ }^{97}$ İşte bu akımın oluşmaya başladığ 1 1850'li yıllardan sonra araştırmacıların büyük çoğunluğu eserlerini artık, birinci el yazma kaynaklarını yerinde görmek suretiyle kaleme alıyorlard1. Bunlara örnek olarak, Aloys Sprenger'in üç ciltten oluşan "Das Leben und die Lehre Mohammad"98 ini verebiliriz: Sprenger bu eserini yazmak için Hindistan'da uzun yıllar kalmış, bu sayede de önemli yazma eserleri görme firsatı elde etmiştir. ${ }^{99}$ Onun gibi uzun yıllar Hindistan'da araştırmalar yapan William Muir'in yazdığı dört ciltlik "Life of Mahomet" adlı eser de bu açıdan zikredilmeye değerdir. ${ }^{100}$ Daha çok eleştirel türde eser verildiğinden bu döneme "tarihsel-kritik oryantalizm dönem" adı da verildiğini yukarıda söylemiştik. Bundan dolayı da bu dönemde, önceleri, Hz. Peygamber ve O'nun hayatı hakkında eleştirel türde yazılan eserleri, sonraları Kur'an hakkında ve Hadis hakkında olanları takip etti. Theodor Nöldeke (1836-1930)'nin 1865'de Kur'an'la ilgili yazdığı eser bu bağlamda ilk örneği oluşturur. ${ }^{101}$ Hadis ilminde ise Goldzieher (1850-1921)'in eserleri ilk örnekleri teşkil eder. ${ }^{102}$

Oryantalizm çalışmalarının ikinci döneminde başlayan Kelam çalışmaları, bu son dönemde de yoğunlaşarak devam etti. Bu dönemde özellikle, Kelam ekolleri hakkında yazılanlar dikkatimizi çekmektedir. Schmölders'in 1842'de yazdığ 1 "Essai sur les écoles philosophiques chez les Arabes ve Heinrich Ritter'in 1845 yılında yazdığ 1 "Ueber Unsere Kenntniss der arabischen Philosophie" bu anlamda sayılmaya değer olanlardır. Cureton tarafindan Arapça'dan İngilizce'ye, 1842 yılında, bazı bölümleri eksik olarak çevrilen Şehristani'nin

94 Watt-Welch, a.g.e., 28.

95 a.g.e., s. 28.

96 a.g.e., s. 28.

97 Becker, "İslampolitik", s. 310.

98 Berlin 1861-1865)

99 Watt-Welch, a.g.e., s. 29.

100 a.g.e., s. 29.

101 Watt-Welch, a.g.e., s. 30.

102 a.g.e, s. 33. 
"el-Milel ve'n-Nihâl" adlı eserinin, Theodor Haarbrücker tarafindan 1850'de Arapça'dan tam olarak Almanca'ya çevrilmesi oldukça önemli bir gelişme olarak kabul edilmektedir. ${ }^{103}$ Ancak, bir bakıma İslam mezhepleri tarihi grubuna dahil edilebilecek bu tür çalışmalardan, doğrudan Kelam'la ve Kelam ekolleriyle ilgili olan çalışmalara geçiș ancak 1800'lü yılların sonlarına doğru sağlanabildi. Bu bağlamda, W.R.Sclamaier'in 1880'de yazdığı "Über den Fatalismus der vorislamischen Araber" (İslam Öncesi Arapların Cebriyeciliği Üzerine) adlı doktora tezi örnek olarak verilebilir. Bu tarihten itibaren doğrudan kelamla ilgili araştırma ve eserlerin oldukça arttığı gözlenmektedir. ${ }^{104}$

Araştırmaların yerinde ve mevcut kütüphanelerdeki yazma eserlerden yararlanmak suretiyle yapılmaya gayret edilmesi, Arapça eğitiminin önemini gündeme getirdi. Öyle ki, 1887 yılında Berlin'de "Doğu Dilleri Enstitüsü' nün kurulması sırasında, buranın müdürlüğüne getirilen Ernst Schau, Asya ve Afrika ülkeleriyle olan ilişkilerin daha da artmasında en önemli unsurun, bu ülkelerin dillerine en iyi şekilde hakim olmak olduğunu söylemiştir. ${ }^{105}$ Sonraki yıllarda Almanya'nın çeşitli üniversitelerinde Berlin'dekine benzer çok sayıda Doğu dilleri bölümü açıldı. Gerçekten de buralardan mezun olan oryantalistler, oldukça iyi bir dil bilgisine sahip olduklarından, gittikleri Müslüman ülkelerdeki el yazma eserlerine kolayca ulaşabiliyorlar ve bunların edisyon-kritiğini yapmak suretiyle yayınlıyorlardı. Ancak bundan daha da önemlisi, uygulamalı oryantalizm bağlamında olanıdır. O da şudur: Uygulamalı oryantalizm anlayışı esasen hali hazırda olan olgu ve olayların tarihi arka planı ve bunun günümüzdeki yansımalarını inceler. Yani o, eskiyle yetinmez, eskiyi ve onun hali hazırdaki izdüşümlerine bakarak şimdi'yi ve geleceği yönetmeye çalışır. İşte bundan dolayı ona "şimdiyle-aktüelle ilintili oryantalizm" (gegenwartsbezogene Orientalistik) de denmektedir. ${ }^{106}$ Günlük siyaseti takip etmenin en önemli aracı ise dildir. Bundan dolayı Avrupa'da Arapça başta olmak üzere Doğu dilleri öğretimine büyük önem verilmiştir.

20. yüzyılın başından itibaren, uygulamalı oryantalizm anlayışının bir gereği olarak daha çok, yukarıda bahsedilen günlük-takip edilen bu yayılmacı politikaya hizmet edecek, eserler verilmeye başlandı. Daha önceleri, Müslümanların tarihi, dili ve inançları hakkında yapılan genel araştırmalar

103 el-Milel ve'n-Nihâl (Almanca'ya çev. Theodor Haarbrücker), Hildesheim 1969, s. V.

104 Bu konuda geniş bilgi için bkz., Özcan Taşcı, “Almanya'da Kelam Çalışmaları”, Dini Araştırmalar, c. 6, s. 18, s. 211-220.

105 Bkz., Ernst Schau, Denkschrift Über das Seminar für orientalische Sprachen an der Königlichen Friedrich-Willhelms Universität zu Berlin von 1887-1912, Berlin 1912, Beilage 1: Denkschrift vom 3. April 1886.

106 "www.wikipedia.org/C.H.Becker" 
özele ve detaya kaymaya başladı. Bu da çalışmaların daha yoğunlaştığını göstermektedir. Örneğin, 19. yüzyılın ikinci yarısının sonuna kadar (takriben 1880'li yıllar) adeta mezhepler tarihi çalışmaları görüntüsü veren Kelam çalışmaları, bu dönemden itibaren sadece kelam tarihi ya da geçmişteki kelam konularıyla değil, güncel ekollerle ve inanç meseleleriyle de ilgilenmeye başlamıştır. Örneğin, Max Horten'ın "Die religiöse Gedankenwelt der gebilditen Muslime im heutigen İslam"107 (Günümüz İslam'nnda Yetiştirilmiş-Eğitimli Müslümanların Dini Düşünceleri) buna iyi bir örnek teşkil etmektedir. C.H.Becker'in eserlerine bakıldı̆̆ında da bu durum açıkça anlaşılmaktadır; o, yazılarında daha çok, güncel siyaseti ilgilendiren konuları tercih etmiştir. ${ }^{108}$ Becker'in en önemli öğrencisi olan Hellmut Ritter'in üzerinde çalıştığı konular da bu noktada zikredilmeye değer görünmektedir. Örneğin o, el-Gazâli'nin, "Kîmîyâ es-Se'âde" sini "Das Elixir der Glückseligkeit" adıyla Almanca'ya 1923 yılında tercüme etmiştir. Bu kitap, Müslümanların büyük çoğunluğu tarafından geçmişte ve günümüzde hala okunan bir kitap olması yönüyle, onların düşüncelerini-inanç sistemlerini doğrudan şekillendirmektedir. Bu yüzden çağdaş Müslümanları daha iyi tanımak için onların büyük rağbet gösterdiği bu eserin, uygulamalı oryantalizm gereği mutlaka bilinmesi gereklidir. Başka bir örnek vermek istiyoruz: Ritter, Türkiye'de halkın büyük bir beğeniyle okuduğu ve izlediği, dolayısıyla da onların gelenek ve kültürlerinin önemli bir parçasını yansıtan, Karagöz ve gölge oyunlarının birincisini1924'de, ikincisini 1941'de, üçüncü ve sonuncusunu da 1953'de, "Karagös. Türkische Schattenspiele." adıyla Almanca'ya tercüme etmiştir. Bu örneklerde de görüleceği üzere, seçilen eserler genelde, ilişkide bulunulan ülke insanının kültürünü, dinini, dolayısıyla da gelenek ve göreneklerini tanıtan türdedir. Bu da onlara karşı geliştirilecek en isabetli siyaseti bulmayı kolaylaştıracaktır (gegenwartsbezogene Orientalistik).

Becker'in ortaya koyduğu, 'her oryantalist, Müslüman ülkeleri, kütüphane ziyaretleri ve öğrenim seyahatleriyle tanımalıdır" ilkesi sonucu, hemen hemen her oryantalist, araştırmalarını yapmak üzere Müslüman ülkelere gidiyor ve oralarda faydalandıkları el yazmalarını, ya yerinde, edisyon-kritiğiyle yayınlıyorlar ya da bunları yanlarında getirmek suretiyle Almanya'da neşrediyorlardı. Bu da “...İstanbul kütüphanelerinin zengin hazinelerinin artık Almanya'nın malı haline..." ${ }^{\prime 09}$ gelmesini sağlamıştı.

107 Halle 1916.

108 Bkz., Becker, İslamstudien, Leipzig 1924-1932, Bd., I-II.

109 "Ritter'in İstanbul'daki çalışmalarıly ilgili bilimsel rapor", München 8. 7. 1933, Hessisches Staatsbiliothek, Nr. 302. (Bu raporun ikinci sayfası eksik olduğundan kimin tarafından yazıldığı tespit edilememektedir) 


\section{Sonuç}

Batıda ortaya çıkan oryantalizm çalışmalarının temelde üç aşamalı olduğu söylenebilir: Bu aşamalardan birincisini, temelde dini amaçlarla yapılanlar oluşturmaktadır. Rönesans ve Aydınlanma dönemlerini kapsayan ikinci aşamada ise, birincisine nazaran, kısmen de olsa, bilgi edinme gayesiyle bilimsel yöntemlerle yapılan araştırmalarla karşılaşmaktayız. Ancak bu dönemde yapılan çalışmalara bakıldı̆̆ında, bunlarının çoğunun, ilk dönemde olduğu gibi, dinsel önyargılarla yapıldığı tespit edilmektedir. Üçüncü ve son aşama ise, büyük oranda Batılı devletlerin yayılmacı-sömürgeci zihniyetlerinin bir sonucu olarak ortaya çıkmıştır:

İşgal ettikleri Müslüman ülkelerde uzun süreli kalmak, onların yeraltı ve yer üstü kaynaklarından azami derecede istifade etmek ve daha fazla bölgeyi kontrolleri altına almak gayesiyle, sömürgeci siyaset güden devlet adamları oryantalistlerle sıkı bir ilişki kurdular; onların da askeri seferlere katılmasını sağladılar ve yayılmacı politikaya katkı sağlayacak çalışmalar yapmaları hususunda onları desteklediler. Zira, Müslüman sömürgeler çoğalmış ve bunların kontrol edilme sorunu gündeme gelmişti; bu da Müslüman halkların, tarih, dil ve inançlar açısından geniş bir tahlile tabi tutulmasını zorunlu kılmıştı. Bunu yapacak da elbette oryantalistlerden başkası değildi. Bu durum, oryantalistlerin sömürge bölgelerinde bizzat devlet memuru olarak atanmaları sonucunu doğurdu. Onların görevi, özellikle ayaklanma baş gösteren sömürge bölgelerinde bulunmak suretiyle, bu ayaklanmaların arkasındaki muhtemel, tarihsel, dilsel ve dinsel sebepleri tespit etmek ve bunu ilgili mercilere rapor etmekti. Bir başka deyişle, onların teoride ürettiği veriler, sömürgelerde takip edilen siyaseti doğrudan yönlendiriyor, bunlar pratikte doğrudan uygulanıyordu. Böylece müsteşrikler, oryantalizm çalışmalarını sadece politik ve siyasal amaçlarla yapmakla karşı karşıya kalmışlardır. Başka bir ifadeyle, oryantalizm çalışmaları tam anlamıyla günlük-takip edilen siyasetin tekeline girmiştir. İşte bu tür oryantalizm anlayışı, 'uygulamalı oryantalizm' (angewandte-gegenwartsbezogene Orientalistik) olarak isimlendirilmektedir. ${ }^{110}$

Bu akımın ilk temsilcisi olarak Hollandalı C.Snouck-Hurgronje (18571936) kabul edilmektedir, zira o, "oryantalizm çalışmalarını sırf politik ve siyasal gayelerle yürütmesi" için doğrudan devlet memurluğu makamına getirilen ilk kişidir. ${ }^{111}$ Onu diğer oryantalistler takip etti. Ancak bu akımın

110 Bkz., Peter Heine, "C.Snouck-Hurgronje Versus C.H.Becker. Ein Beitrag zur Geschichte der angewandten Orientalistik", in: Die Welt des İslams 23/4 (1984), s. 387.

111 Heine, a.g.e., Berlin 1989, s. 30. 
en önemli temsilcisi olarak, meşhur Alman oryantalist C.H.Becker (18761933) gösterilmektedir. Çünkü Becker, bilim adamlı̆̆ı kimliği altında yaptığ çalışmaları, sadece devlet memuru olarak uygulamakla kalmamış, aynı zamanda Kültür Bakanlığı (1925-1930) döneminde bir politikacı ve devlet adamı olarak bu politikaları bizzat yönetmiştir. Becker'e göre her oryantalist, devletin takip edeceği İslam politikasına çalışmalarıyla destek veren devletin bir memurudur ve yine her oryantalist Müslüman dünyayı öğrenim seyahatleri ve kütüphane ziyaretleriyle tanımalıdır. ${ }^{112} \mathrm{Bu}$ da uygulamalı oryantalizm anlayışının en önemli yönü olarak karşımıza çıkmaktadır.

112 Hanisch, a.g.m., s. 111. 